\title{
実大鉄骨造体育館試験体の設計および応答の概要
}

\author{
$\mathrm{E}$-ディフェンスを用いた吊り天井を有する体育館の天井脱落被害再現実験その 1
}

\section{DESIGN AND STRUCTURAL RESPONSE OF FULL-SCALE STEEL GYMNASIUM SPECIMEN}

E-Defense shake table experiment on collapse mechanism of wide-area suspended ceiling in gymnasium part 1

\author{
佐々木 智大*1, 青井 淳 ${ }^{* 2}$, 田川浩 之*3, 梶原 浩 ${ }^{* 4}$, 佐 藤 大 樹*5 \\ 壁谷澤 寿海*6, 清 家 剛*7, 山田 哲*8, 福 山 洋*9 \\ Tomohiro SASAKI, Atsushi AOI, Hiroyuki TAGAWA, \\ Koichi KAJIWARA, Daiki SATO, Toshimi KABEYASAWA, \\ Tsuyoshi SEIKE, Satoshi YAMADA and Hiroshi FUKUYAMA
}

\begin{abstract}
During the 2011 off the Pacific coast of Tohoku Earthquake, many suspended ceilings and other suspended equipment fell down causing fatal accidents even in Tokyo, while relatively minor damages were observed to the structures. To mitigate such severe damage to the ceilings during earthquakes, new seismic design code for suspended ceiling system was issued by the Ministry of Land, Infrastructure, Transport and Tourism. However, the mechanism has not yet been understood clearly yet why and how the ceilings fell down due to the earthquake motion. A new research project started to clarify the collapse mechanism of wide-area ceiling system and to develop its countermeasures. Full-scale shake-table experiments of the wide-area ceiling system in a steel gymnasium was conducted as the first phase in 2014. This paper outlines the test plans and the observed global responses of the structural members and the ceilings.
\end{abstract}

Keywords : Gymnasium, Steel Structure, Seismic Design, Full-scale shake table experiment, E-D efense 体育館，鋼構造，而震設計，実大振動実験，Eーディフェンス

\section{1. はじめに}

大地震発生時の避難拠点となる体育館などの大規模建築物につい ては，災害発生後も避難拠点として使用可能であり，余震にも耐え うる施設であることが期待されている。しかし，東日本大震災では 本震に加えて最大震度 6 弱以上の余震が多数回発生し，体育館など では柱脚の損傷やブレース材が破断するなどの構造部材の被害およ び天井材等の非構造部材や照明等の設備機器の落下被害等により, 地震後の避難拠点としての機能を満たさない事例が報告されている 1-4)。また, 多数の施設で天井等の落下が発生し死傷者が発生したと 報道されている。このような被害は人命保護の観点から，あっては ならない事象であり,最優先で対策されるべき課題であるといえる。

2011 年東北地方太平洋沖地震において, 広範囲の施設で多数の被 害が発生したことを受け, 国土交通省では建築基準法施行令の改正
5) と関連告示の制定 6)を行い，技術解説書 7)も示され，平成 26 年 4 月 1 日より施行されている(以下,これらを $\mathrm{H} 26$ 技術基準とする)。 一方，学術的な面から見ると，天井が脱落に至る過程に関するデー 夕は依然として不足しており，そのメカニズムについてはまだ明ら かになっていない部分も多い。また，これまでの天井の耐震性に関 する実験的研究では, 剛なフレーム構造の下に天井をつり下げて行 われた振動実験の事例が多く, 空間構造特有の複雑な挙動が天井に 及ぼす影響に関してはさらなる検討が求められている。

体育館の振動特性に関寸る研究では，竹内らが様々な検討を進め ている。円筒シェル構造の半開角，面外剛性および下部構造の剛性 を変化させたモデルに対して応答評価手法を検討し，屋根面におけ る最大応答加速度が，屋根逆対称 1 次モードと等価 1 質点系モデル の固有周期比 $\mathrm{R}_{\mathrm{T}}$ の関数で表される応答増幅率で評価できることを

\footnotetext{
*1 国立研究開発法人防災科学技術研究所兵庫耐震工学研究センター 主任研究員 ·博士 (工学

*2 (株)竹中工務店技術研究所 研究員 - 修士 (工学)

(前 防災科学技術研究所)

*3 武庫川女子大学建築学科 准教授 $\cdot$ Ph. D.

(前防災科学技術研究所)

*4 国立研究開発法人防災科学技術研究所兵庫耐震工学研究センター センター長・博士 (工学)

*5 東京工業大学科学技術創成研究院 准教授 - 博士 (工学)

(前防災科学技術研究所)

*6 東京大学地震研究所 教授. 工博

*7 東京大学大学院社会文化環境学専攻 准教授. 博士 (工学)

*8 東京工業大学科学技術創成研究院 教授. 博士 (工学)

*9 国土技術政策総合研究所住宅研究部 部長·工博
}

Senior Researcher, Earthquake Disaster Mitigation Division, Natl. Res. Inst for Earth Science and Disaster Resilience, Dr. Eng.

Researcher, R\&D Inst., Takenaka Corp, M. Eng.

(Former Natl. Res. Inst. for Earth Science and Disaster Resilience)

Assoc. Prof., Dept. Arch., Mukogawa Women's Univ, Ph. D.

(Former Natl. Res. Inst. for Earth Science and Disaster Resilience)

Manager, Earthquake Disaster Mitigation Division, Natl. Res. Inst. for Earth

Science and Disaster Resilience, Dr. Eng.

Assoc. Prof., FIRST, IIR, Tokyo Tech, Dr. Eng.

(Former Natl. Res. Inst. for Earth Science and Disaster Resilience)

Prof., Earthquake Res. Inst., The Univ. of Tokyo, Dr. Eng.

Assoc. Prof., Dept. Socio-Cultural Env. Studies, The Univ. of Tokyo, Dr. Eng.

Prof., FIRST, IIR,, Tokyo Tech., Dr. Eng.

Director, Housing Dept., Natl. Inst. for Land and Infrastructure Mgt., Dr. Eng. 
示している ${ }^{8)}$ 。また, 屋根部の質量 $M_{R}$ に対する全体系の質量 $M_{\text {eq }}$ の比 $\mathrm{R}_{M}$ が応答増幅率に与える影響を検討し, これを考慮した簡易 な応答評価法を提案している 9)。

本研究では, 複雑な挙動をする空間構造を実験にて再現し, 屋根 につり下げられた天井の時々刻々と変化する挙動を詳細に記録し, 脱落に至るメカニズムを明らかにすることを目指し, 吊り天井を有 する実物大の体育館を模擬する試験体を設計・製作し, その加振実 験を実施した。

本論文では，実大体育館試験体の構造設計に関する情報をまとめ るとともに, 試験体の応答に関する概要についてまとめ, 続報にて 述べる構造体の損傷および天井の脱落に至るメカニズムに関する議 論等において必要となる計測や加振に関する実験計画と試験体の情 報等の共通する事項について提供する。空間構造特有の複雑な挙動 や各部材の塑性化の状況などの構造体の応答の分析と, 天井の設計 及び脱落に至るメカニズムに関しては続報にて述べる。

\section{2. 実験概要}

\section{1 試験体の設計方針}

試験体は, 小中学校で使用される体育館を想定して設計を行った。 ただし, ステージ等の付随する部分は省略し, アリーナ部分のみを モデル化した。図 1 および写真 1 は本実験に使用した試験体である。 表 1 に試験体の主な仕様を示す。

文部科学省の有識者会議が実施した学校施設における非構造部材 の耐震対策に関する調査報告 10 )を整理すると, 平均的な屋内運動場 等施設の平面寸法は約 $25 \mathrm{~m} \times 30 \mathrm{~m}$ である。搬入・設置作業等におけ る制約なども考慮した結果, 実験可能な最大の寸法である $18.6 \mathrm{~m} \times$ $30 \mathrm{~m}$ という平面寸法とした。この平面寸法は, 内部にバスケットコ 一トが 1 面取れる大きさであり， E一ディフェンス震動台の寸法 $15 \mathrm{~m} \times 20 \mathrm{~m}$ を越える寸法である。なお, 東北地方太平洋沖地震にお ける被害の調查分析によれば, 天井の全面脱落被害はスパンが $20 \mathrm{~m}$ 以上の体育館で発生しており, スパンが大きいほど被害棟数も多い 結果となっている ${ }^{1-4)}$ 。実験上の制約から $18.6 \mathrm{~m}$ のスパンと全面脱 落が多数生じた寸法にはわずかに及ばない寸法としたものの， $20 \mathrm{~m}$
に近い寸法となっている。

建物試験体の屋根については, 既存の体育館で採用例の多い山形 屋根とした。スパンと屋根の高さの比であるライズスパン比と東日 本大震災における被害との関連を分析した結果によると，ライズス パン比が 0.1 から 0.15 の間にある屋内運動場等施設の棟数が多く, 全面脱落被害も多いことがわかっている1-4)。そのため, スパンライ ズ比が 0.15 となるよう, 屋根勾配を 10:3 とした。建物試験体の高 さは最も高いところで $9.09 \mathrm{~m}$ である。

試験体には屋根面と同じ勾配を有する吊り天井を設置する。天井 の水平投影面積は約 $558 \mathrm{~m}^{2}(=30 \mathrm{~m} \times 18.6 \mathrm{~m})$, 頂部での天井面の高さ は約 $7.5 \mathrm{~m}$ であり，H26 技術基準によれば，この天井は特定天井で ある。今回の実験では，実験期間中に天井の張り替えを行い，2 回 実験を実施した。1 回目は, 脱落防止対策が施されていない既存の 天井を模擬した天井（以下，未対策天井とする）であり，主に落下 被害メカニズムの解明に主眼を置いている。2 回目は, H26 技術基 準の仕様ルートに基づいて設計された, 脱落防止対策の施された天 井（以下，耐震天井と寸る）であり，耐震天井の耐震性と耐震余裕 度の検証を行う。而震天井の実験では, 頂部を境に 2 種類の天井を 施工し, $\mathrm{Y} 1 \sim \mathrm{Y} 4$ 通り側には高強度な部材を用いて設計水平震度 2.2 とした耐震天井(以下， $2.2 \mathrm{G}$ 耐震天井とする)を, $\mathrm{Y} 4 \sim \mathrm{Y} 7$ 通り側に

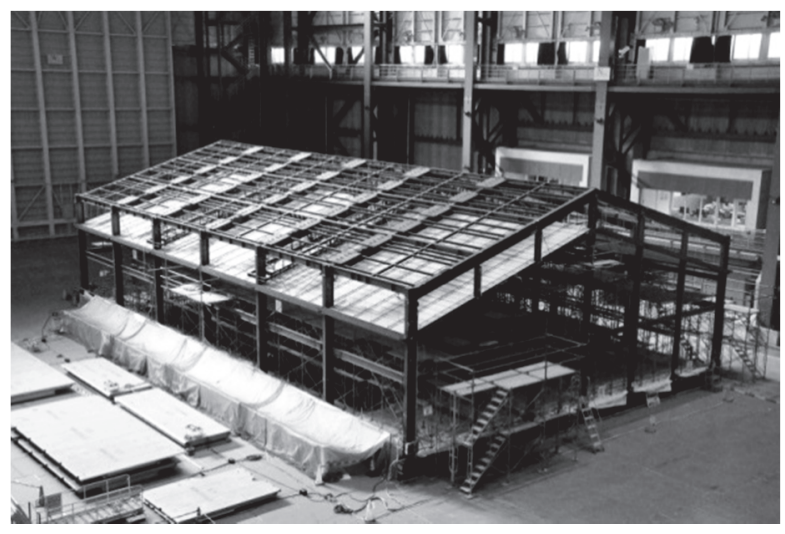

写真 1 実大体育館試験体外観
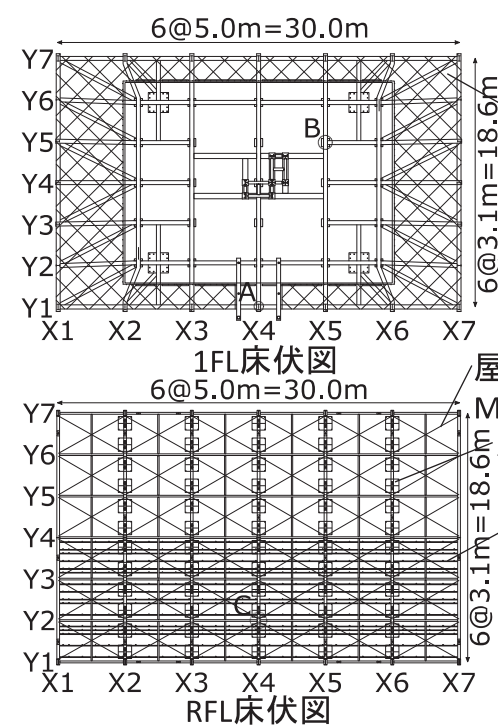

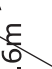

$\infty$ 震動台からの II 張り出し部 エ・・スパンド હॄ) メタル床 屋根ブレース M16(SS400) 屋根おもり PL-32(2枚重ね)

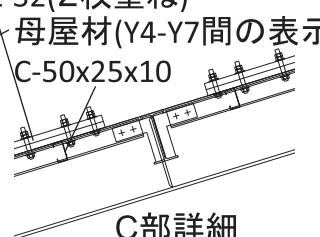

C部詳細

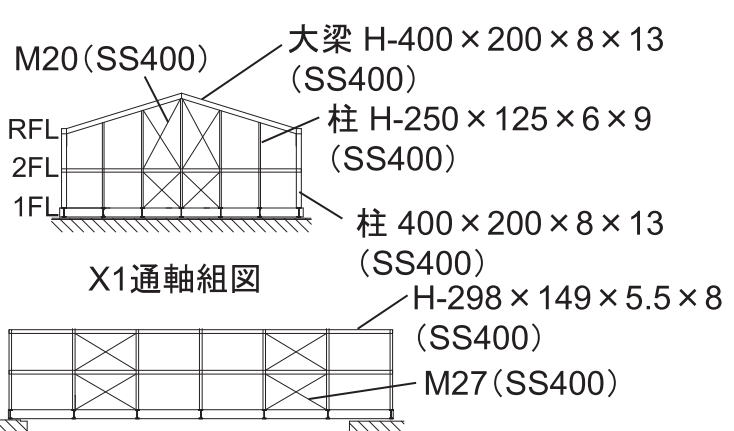

Y1通軸組図

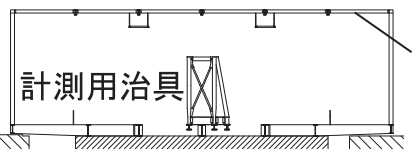

$\mathrm{H}-248 \times 124 \times 5 \times 8$ (SS400)

図 1 実大体育館試験体 
表 1 建物試験体の主な仕様

\begin{tabular}{|c|c|c|}
\hline \multicolumn{2}{|r|}{ 項目 } & 仕様 \\
\hline \multicolumn{2}{|r|}{ 構造, 階数 } & 鉄骨造 平屋建て \\
\hline \multirow{3}{*}{ 質 } & 上部建物 & 71t（屋根錘は除く） \\
\hline & 屋根錘 & $30 \mathrm{t}$ \\
\hline & $\begin{array}{l}\text { 全構造部材 } \\
\text { 合計 }\end{array}$ & $230 \mathrm{t}$ \\
\hline \multicolumn{2}{|r|}{ 最大高さ } & $9.090 \mathrm{~m}$ \\
\hline \multicolumn{2}{|r|}{ 平面寸法 } & $\begin{array}{c}30.0 \mathrm{~m} \times 18.6 \mathrm{~m} \\
(6 \text { スパン } \times 6 \text { スパン })\end{array}$ \\
\hline \multicolumn{2}{|r|}{ 設計 } & $\begin{array}{l}\text { 許容応力度設計 }\left(\mathrm{C}_{0}=0.2\right) \\
\text { 地震時保有水平耐力に } \\
\text { よる照查を実施 }\end{array}$ \\
\hline \multirow{6}{*}{$\begin{array}{l}\text { 使 } \\
\text { 用 } \\
\text { 部 } \\
\text { 材 }\end{array}$} & 柱(妻面は除く) & $\mathrm{H} 400 \times 200 \times 8 \times 13(\mathrm{SS} 400)$ \\
\hline & 妻面の柱 & $\begin{array}{l}\mathrm{H} 250 \times 125 \times 6 \times 9(\mathrm{SS} 400) \\
\mathrm{H} 300 \times 150 \times 6.5 \times 9(\mathrm{SS} 400) \\
\mathrm{H} 400 \times 200 \times 8 \times 13(\mathrm{SS} 400)\end{array}$ \\
\hline & 大梁 & $\mathrm{H} 400 \times 200 \times 8 \times 13(\mathrm{SS} 400)$ \\
\hline & 小梁 & H248×124×5×8(SS400) \\
\hline & $\begin{array}{l}\text { 鉛直 } \\
\text { ブレース }\end{array}$ & $\begin{array}{l}\text { M20, M27 (SNR400B) } \\
\text { T.B.付き (パイプ式) }\end{array}$ \\
\hline & $\begin{array}{c}\text { 水平 } \\
\text { ブレース }\end{array}$ & $\begin{array}{l}\text { M16 (SNR400B) } \\
\text { T.B.付き (パイプ式) }\end{array}$ \\
\hline
\end{tabular}

はJIS 規格材を主たる部材として構成し, 設計水平震度 1.1 とした 耐震天井(以下， $1.1 \mathrm{G}$ 耐震天井とする)を設置した。また, 天井の下 には脱落防止対策の一環として, ワイヤーとネットの組み合わせに よるフェイルセーフ機能を取り付ける。天井およびフェイルセーフ 機能の仕様の詳細は続報以降で述べる。

\section{2 試験体構造設計}

構造設計では, 標準層せん断力係数 $\mathrm{C}_{0}=0.2$ に対して許容応力度 設計を行った。妻面以外の柱および大梁は $\mathrm{H} 400 \times 200 \times 8 \times 13$ ，小 梁は $\mathrm{H} 248 \times 124 \times 5 \times 8$ ，妻面の柱は $\mathrm{H} 250 \times 125 \times 6 \times 9, \mathrm{H} 300 \times$ $150 \times 6.5 \times 9$ である。既存体育館の構造計画・振動性状を模擬する ため, 既存体育館でよく用いられる細幅 $\mathrm{H}$ 形鋼を使用した。これら に使用寸る鋼材種は SS400 材とした。主要な構造部材のミルシート および材料試験結果を参照した機械的性質を表 2 に示す。また, 壁 ブレースは, 妻面は径 $20 \mathrm{~mm}$, それ以外は径 $27 \mathrm{~mm}$ のターンバック ルブレースを, 屋根ブレースは径 $16 \mathrm{~mm}$ のターンバックルブレース とした。これらの鋼材種は SNR400B である。接合部で損傷するこ とがないように，保有耐力接合としている。一般的に体育館の設計 では, 柱および梁の断面寸法は, 長期荷重で決まることが多く, 本 試験体も同様である。

基礎梁については, 震動台から張り出した部分の振動を抑えられ るだけの十分な大きさの梁として, $\mathrm{H} 900 \times 300 \times 16 \times 28$ (一部テー パー部有り）を使用した。また，弱軸およびねじれによる振動を抑 えられるよう十分な量の補剛材を設け, 弱軸およびねじれの剛性を 高めている。

基礎梁上に柱を固定する方法として、板厚 $32 \mathrm{~mm}$ のベースプレー 卜を M42, 長さ $732 \mathrm{~mm}$, 材質 ABR490 のアンカーボルト 4 本で固 定する構造とした。この柱脚部の回転剛性と基礎梁の張り出しによ る剛性が上部構造の応答に大きく影響する。現実の体育館の挙動が 再現できるようベースプレート，アンカーボルト等を設計した。

図 2 は, $\mathrm{Ai}$ 分布による梁間方向のプッシュオーバー解析の結果 を， $\mathrm{N}$ 值 20 の砂地盤上に $2 \mathrm{~m} \times 2 \mathrm{~m}$ の直接基礎を有する体育館があ
表 2 構造部材の機械的性質

\begin{tabular}{|c|c|c|c|c|}
\hline \multicolumn{2}{|c|}{ 部位(鋼種) } & $\begin{array}{c}\text { 降伏点 } \\
(\mathrm{N} / \mathrm{mm} 2)\end{array}$ & $\begin{array}{c}\text { 引張強さ } \\
(\mathrm{N} / \mathrm{mm} 2)\end{array}$ & $\begin{array}{c}\text { 伸び } \\
(\%)\end{array}$ \\
\hline \multicolumn{2}{|c|}{ 柱(SS400) } & 299 & 443 & 33 \\
\hline \multicolumn{2}{|c|}{ 大梁(SS400) } & 330 & 444 & 31 \\
\hline \multirow{2}{*}{$\begin{array}{c}\text { ブレース材 } \\
\text { (SNR400B) }\end{array}$} & $\mathrm{M} 27$ & 313 & 482 & 31 \\
\cline { 2 - 5 } & $\mathrm{M} 20$ & 314 & 480 & 27 \\
\cline { 2 - 5 } & $\mathrm{M} 16$ & 291 & 446 & 24 \\
\hline
\end{tabular}

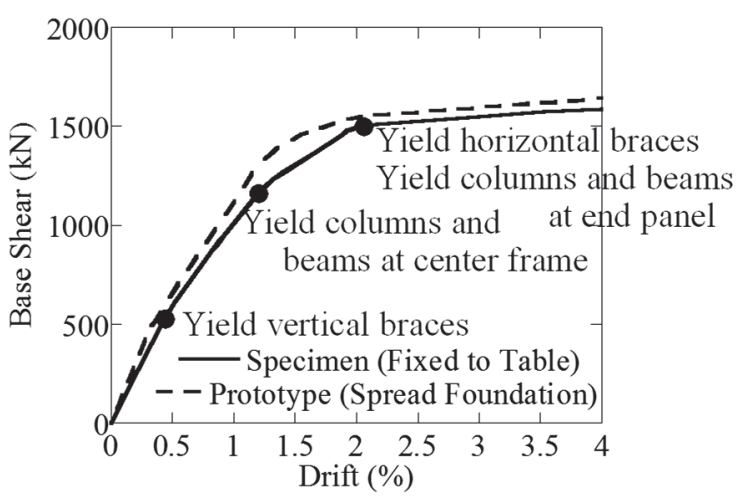

図 2 荷重増分解析結果（柱脚固定度の比較）

表 3 地震時保有水平耐力の照査

\begin{tabular}{|c|c|r|r|r|r|r|}
\hline \multirow{2}{*}{ 方向 } & 階 & Ds 值 & $\begin{array}{c}\text { 基淮保 } \\
\text { 有耐力 } \\
\text { Qud }\end{array}$ & $\begin{array}{c}\text { 必要保 } \\
\text { 有耐力 } \\
\text { Qun }\end{array}$ & $\begin{array}{c}\text { 保有 } \\
\text { 耐力 } \\
\text { Qu }\end{array}$ & Qu/Qun \\
\hline \multirow{2}{*}{ 桁行 } & 1 & 0.45 & $835 \mathrm{kN}$ & $376 \mathrm{kN}$ & $631 \mathrm{kN}$ & 1.68 \\
\cline { 2 - 7 } & 2 & 0.45 & $1014 \mathrm{kN}$ & $456 \mathrm{kN}$ & $776 \mathrm{kN}$ & 1.68 \\
\hline \multirow{2}{*}{ 梁間 } & 1 & 0.40 & $835 \mathrm{kN}$ & $334 \mathrm{kN}$ & $809 \mathrm{kN}$ & 2.42 \\
\cline { 2 - 7 } & 2 & 0.40 & $1014 \mathrm{kN}$ & $406 \mathrm{kN}$ & $983 \mathrm{kN}$ & 2.42 \\
\hline
\end{tabular}

ると想定したプロトタイプの結果と,今回実験に使用した試験体の, 基礎梁が震動台上から張り出している効果を見込んだ解析モデルに て求めた結果とを比較したものである。図 2 に示したとおり, 試験 体はプロトタイプの荷重〜変位関係を再現できている。

許容応力度法による 1 次設計の後に, 地震時保有水平耐力に基づ く地震時安全性の照查を実施した。ここでは, Ai 分布によるプッシ ユオーバー解析により層間変形角が $1 / 100$ に達したときの層せん断 力を求め, これを地震時保有水平耐力としている。表 3 にその結果 を示すが, 地震時保有水平耐力は, 梁間方向には必要耐力の 2.42 倍, 桁行方向には 1.68 倍あり，十分な耐力があることがわかる。

吊り天井の動きを外部から確認するため, 屋根, 外壁材は省略し た。ただし，屋根材の質量の分については，振動特性に与える影響 が大きいことから，これと等価な質量を持つ鋼板 $(1 \mathrm{~m} \times 1 \mathrm{~m} \times 64 \mathrm{~mm})$ を大梁の上に 60 枚（以下，これを屋根錘とする）設置し, 建物試験 体の応答が実際の体育館の挙動を再現できるよう調整している.

試験体の質量については，上部建物は屋根錘を除いて 71t，屋根 錘は $30 \mathrm{t}$ であり，建物試験体の全質量は $230 \mathrm{t}$ である。

屋根を剛体とし，柱，梁などの屋根を支持する部分のみが変形す るとした場合の 1 次固有周期と屋根の逆対称 1 次モード固有周期を 求めるとそれぞれ 0.310 秒および 0.228 秒で有り，これらの固有周 期比 $\mathrm{R}_{\mathrm{T}}$ を求めると 1.36 である。また, 屋根と支持構造の重量和を, 屋根の重量で除した比 $\mathrm{R}_{\mathrm{M}}$ は, 1.29 となる。文献 8,9 )に基づき屋根 
- 加速度計

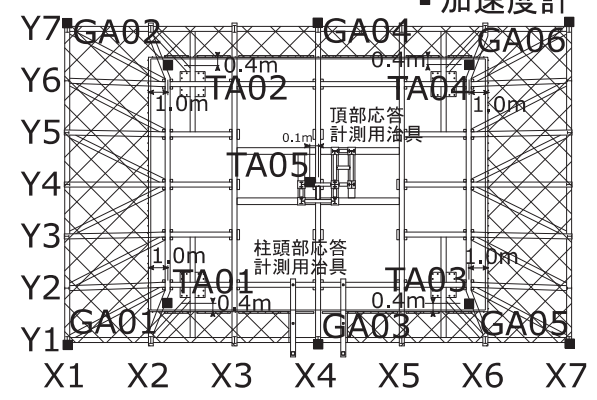

(i) 震動台と柱脚

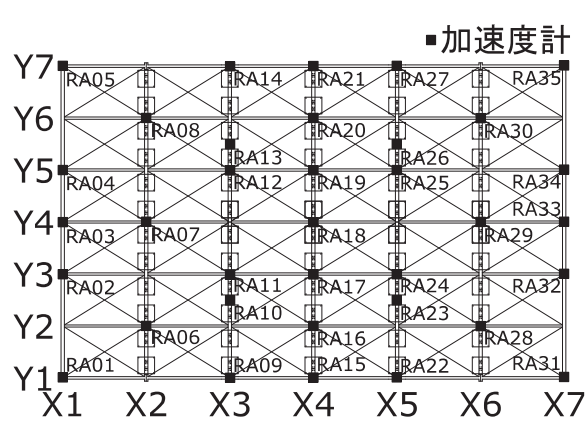

(ii) 屋根面

(a) 加速度計測

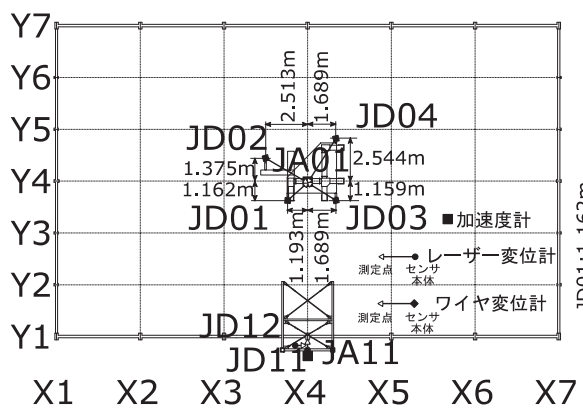

(i) 屋根頂部および柱頭部

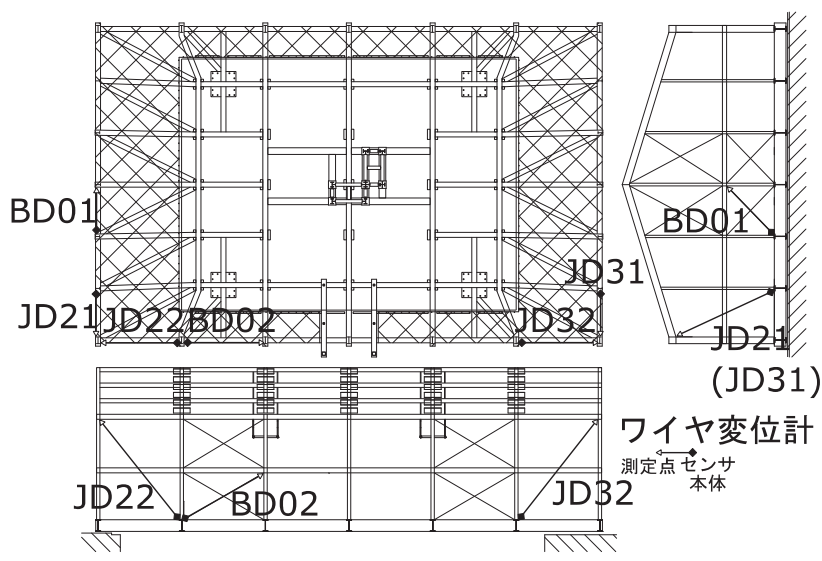

(ii) ブレース変位

(b) 変位計測

図 3 主要な構造部材の計測位置

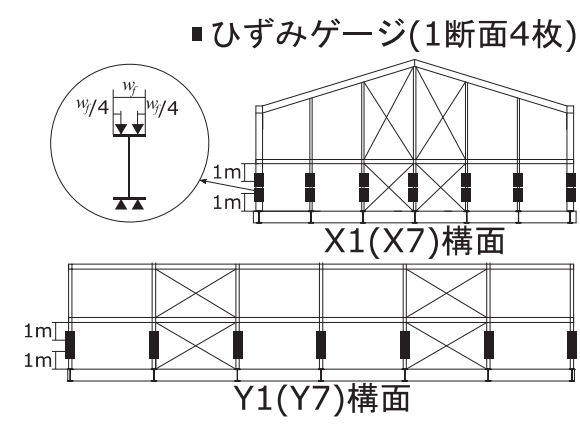

(a) 柱

ムひずみゲージ(片面1枚)

・ひずみゲージ(両面2枚,曲げ消去)
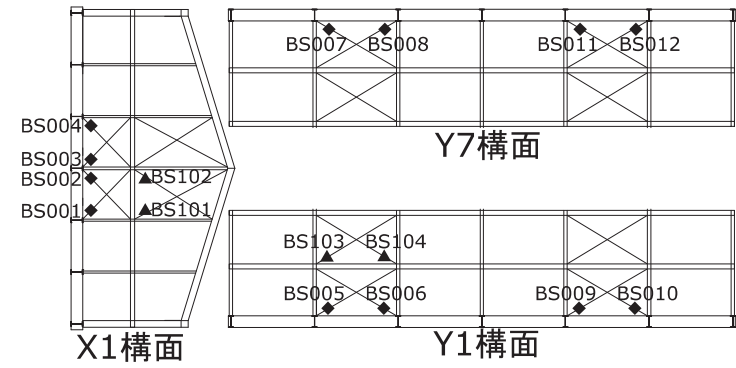

(c) 壁ブレース

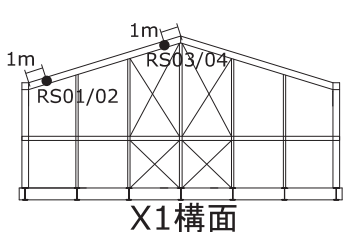

・ひずみゲージ(1断面2枚)
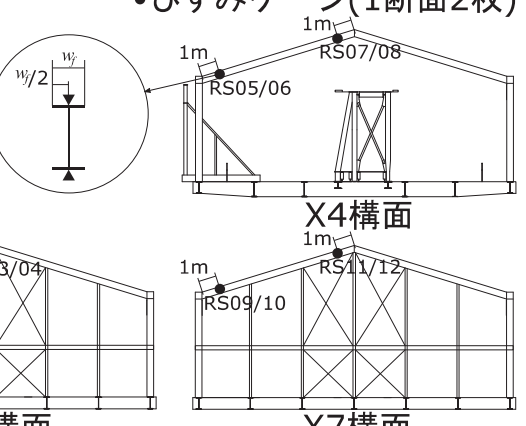

(b) 梁

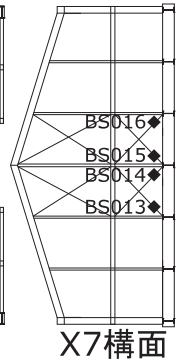

図 4 ひずみゲージ貼り付け位置
ムひずみゲージ(片面1枚)

・ひずみゲージ(両面2枚,曲げ消去)

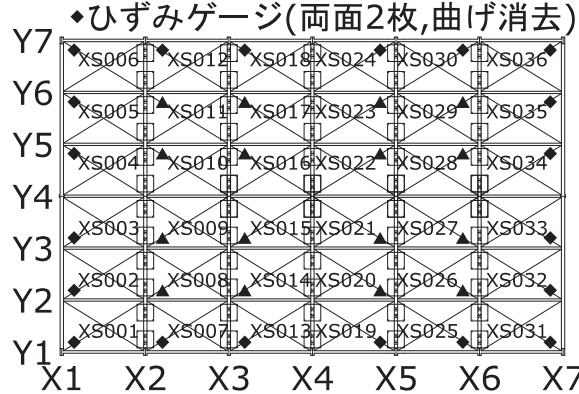

(d) 屋根ブレース
面の応答増幅係数を求めると, 梁間方向入力における水平方向の応 答増幅係数は 1.28 , 鉛直方向の応答増幅係数は 1.08 である。

2. 3 計測計画
本実験での主な計測項目は，(1)震動台，基礎架台，屋根面，天井 面での加速度, (2)ワイヤー式変位計による屋根頂部の変位量, (3)レ ーザー変位計による柱頂部での変位量, (4)柱, 大梁, 壁ブレース, 


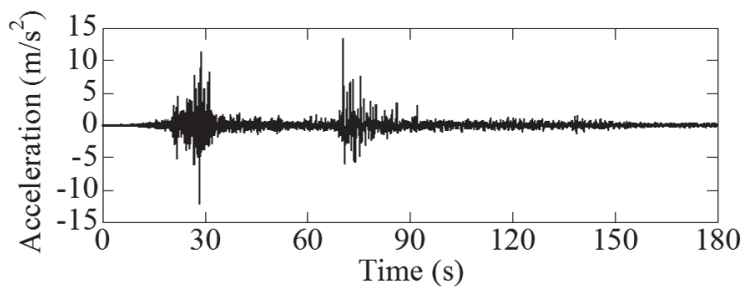

(a) K-NET 仙台波

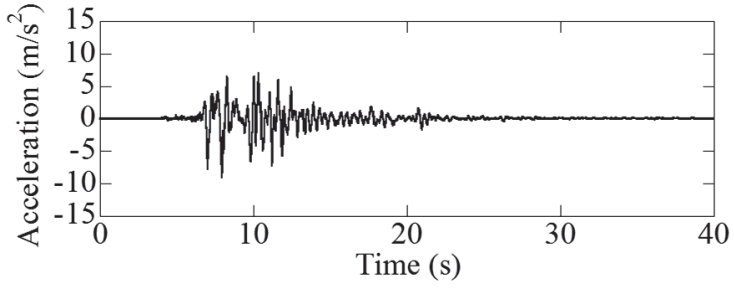

(b) JMA 神戸波

図 5 入力地震動（梁間方向）

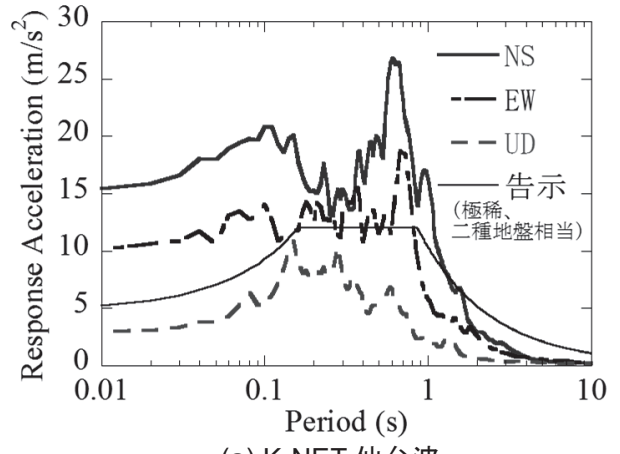

(a) K-NET 仙台波

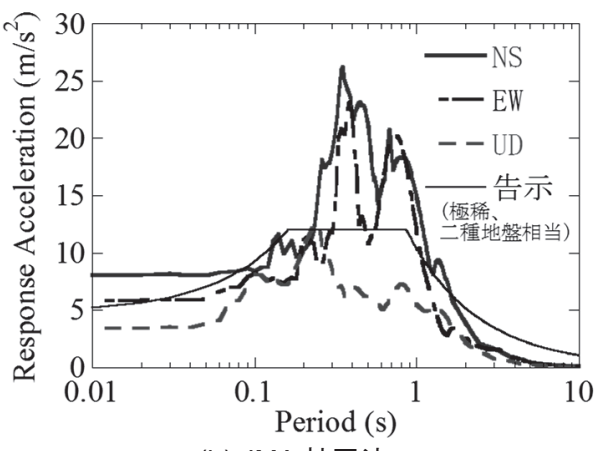

(b) JMA 神戸波

図 6 応答スペクトル(減衰定数 $5 \%)$

表 4 加振計画

\begin{tabular}{|c|c|c|c|c|c|c|}
\hline 実験日 & $\begin{array}{c}\text { 天井 } \\
\text { 試験体 }\end{array}$ & 加振波 & $\begin{array}{c}\text { 入力 } \\
\text { レベル }\end{array}$ & $\begin{array}{c}\text { 震動台 } \\
\text { 加速度 } \\
\text { (梁間方向) }\end{array}$ & 震度 & $\begin{array}{c}\text { 目標屋根面 } \\
\text { 加速度 } \\
\text { (梁間方向) }\end{array}$ \\
\hline \multirow[b]{2}{*}{$2014 / 1 / 27$} & \multirow{5}{*}{$\begin{array}{c}\text { 未対策 } \\
\text { 天井 }\end{array}$} & K-NET 仙台波 & $5 \%$ & $0.76 \mathrm{~m} / \mathrm{s}^{2}$ & 震度 4 & $1.5 \mathrm{~m} / \mathrm{s}^{2}$ \\
\hline & & JMA 神戸波 & $5 \%$ & $0.30 \mathrm{~m} / \mathrm{s}^{2}$ & 震度 4 & $1.2 \mathrm{~m} / \mathrm{s}^{2}$ \\
\hline \multirow{3}{*}{$2014 / 1 / 28$} & & \multirow{3}{*}{ K-NET 仙台波 } & $25 \%$ & $3.79 \mathrm{~m} / \mathrm{s}^{2}$ & 震度 5 強 & $7.3 \mathrm{~m} / \mathrm{s}^{2}$ \\
\hline & & & $50 \%$ & $7.59 \mathrm{~m} / \mathrm{s}^{2}$ & 震度 6 弱 & $15.7 \mathrm{~m} / \mathrm{s}^{2}$ \\
\hline & & & $50 \%$ & $7.59 \mathrm{~m} / \mathrm{s}^{2}$ & 震度 6 弱 & $15.7 \mathrm{~m} / \mathrm{s}^{2}$ \\
\hline \multirow{3}{*}{$2014 / 2 / 27$} & \multirow{7}{*}{$\begin{array}{l}1.1 \mathrm{G} \text { 耐 } \\
\text { 震天井 } \\
2.2 \mathrm{G} \text { 耐 } \\
\text { 震天井 }\end{array}$} & \multirow{5}{*}{ K-NET 仙台波 } & $5 \%$ & $0.76 \mathrm{~m} / \mathrm{s}^{2}$ & 震度 4 & $1.5 \mathrm{~m} / \mathrm{s}^{2}$ \\
\hline & & & $25 \%$ & $3.79 \mathrm{~m} / \mathrm{s}^{2}$ & 震度 5 強 & $7.3 \mathrm{~m} / \mathrm{s}^{2}$ \\
\hline & & & $50 \%$ & $7.59 \mathrm{~m} / \mathrm{s}^{2}$ & 震度 6 弱 & $15.7 \mathrm{~m} / \mathrm{s}^{2}$ \\
\hline \multirow{4}{*}{$2014 / 2 / 28$} & & & $80 \%$ & $12.14 \mathrm{~m} / \mathrm{s}^{2}$ & 震度 6 強 & $36.9 \mathrm{~m} / \mathrm{s}^{2}$ \\
\hline & & & $100 \%$ & $13.41 \mathrm{~m} / \mathrm{s}^{2}$ & 震度 6 強 & $48.3 \mathrm{~m} / \mathrm{s}^{2}$ \\
\hline & & \multirow{2}{*}{ JMA 神戸波 } & $100 \%$ & $8.05 \mathrm{~m} / \mathrm{s}^{2}$ & 震度 6 強 & $22.9 \mathrm{~m} / \mathrm{s}^{2}$ \\
\hline & & & $150 \%$ & $12.08 \mathrm{~m} / \mathrm{s}^{2}$ & 震度 7 & $33.1 \mathrm{~m} / \mathrm{s}^{2}$ \\
\hline
\end{tabular}

屋根ブレースのひずみ量, (5)ワイヤー式変位計による壁ブレースの 変位量, (6)ばね式変位計による柱脚部の回転量, (7)天井面端部にお ける建物試験体に対する相対変位量, (8)フェイルセーフ機能のター ンバックルに取り付けたひずみゲージによるワイヤーの作用荷重で ある。図 3 に本実験における計測位置のうち, 構造体の加速度およ び変位の主要な計測を, 図 4 に各部材に取り付けたひずみゲージの 貼り付け位置について示す。

また, 試験体内外には合計 23 台のカメラを設置し, 天井裏の脱 落に至るまでの状況や天井の応答, 建物試験体外部から試験体の応 答を確認できるようにした。

\section{4 加振計画}

加振実験では 2011 年東北地方太平洋沖地震において防災科学技 術研究所の強震観測網(K-NET)の仙台観測点で観測された加速度記
録（K-NET 仙台波）および 1995 年兵庫県南部地震において神戸海 洋気象台で観測された加速度記録（JMA 神戸波）を用いる。入力方 向は, K-NET 仙台波, JMA 神戸波いずれも梁間方向に NS 成分, 桁行方向に EW 成分, 上下方向に UD 成分とした。K-NET 仙台波 と JMA 神戸波の梁間方向に入力した NS 成分の時刻歴波形を図 5 に, 減衰定数を $5 \%$ として得られる加速度応答スペクトルを図 6 に 示す。なお、図 6 中には第二種地盤による表層地盤の応答増幅を考 慮した、極稀地震を想定した告示スペクトルも合わせて示す。

実験では, 加速度振幅を適切なレベルに縮小（もしくは拡大）し て入力した。3 次元骨組みモデルによる事前解析に基づき入力レベ ルを検討した。表 4 に本実験における加振計画を示す。未対策天井の実 験では仙台波 $5 \%, 25 \%$ 加振の後, $50 \%$ 加振を 2 回実施した。耐震天 井の実験では，仙台波を $5 \%, 25 \%, 50 \%, 80 \%, 100 \%$ の順で入力 


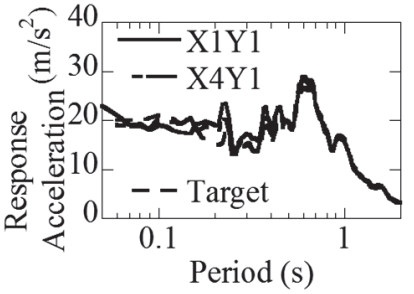

(a) 梁間方向

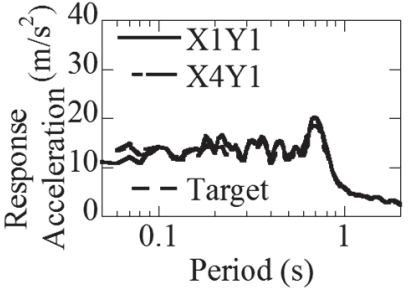

(b) 桁行方向

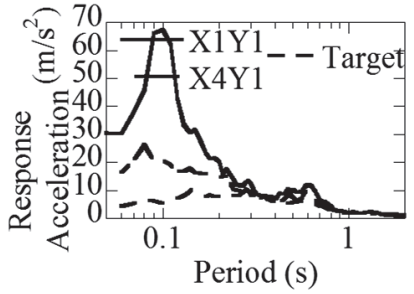

(c) 鉛直方向

図 7 柱脚部の応答スペクトル

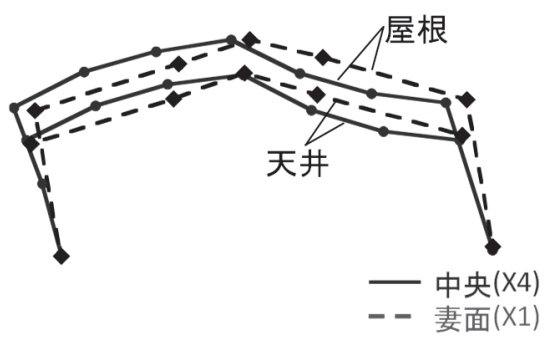

図 8 梁間方向の 1 次固有モード

表 5 実験前の各方向の 1 次固有周期と 減衰定数の推測値

(a) 未対策天井

\begin{tabular}{|c|c|c|}
\hline & 固有周期(秒) & 減衰定数(\%) \\
\hline 梁間方向 & 0.399 & 1.82 \\
\hline 桁行方向 & 0.368 & 2.40 \\
\hline 上下方向 & 0.336 & 2.28 \\
\hline
\end{tabular}

(b) $1.1 \mathrm{G}$ 耐震天井, $2.2 \mathrm{G}$ 耐震天井

\begin{tabular}{|c|c|c|}
\hline & 固有周期(秒) & 減衰定数(\%) \\
\hline 梁間方向 & 0.415 & 2.18 \\
\hline 桁行方向 & 0.358 & 2.21 \\
\hline 上下方向 & 0.332 & 2.06 \\
\hline
\end{tabular}

した後，神戸波を $100 \% ， 150 \%$ で加振した。但し仙台波 100\%は， 加振機の性能限界のため, $20 \mathrm{~Hz}$ の LPF でフィルター処理して入力 している。

なお, 各加振の前後には, 試験体の振動特性把握のためのランダ ム波による加振を行っている。入力方向は梁間, 桁行, 鉛直方向の 3 方向同時で有り, 入力波は $0.1 \sim 35 \mathrm{~Hz}$ の成分が含まれたランダム 波で, 最大加速度が $0.6 \mathrm{~m} / \mathrm{s}^{2}$ 程度となるよう調整した波形である。

\section{3. 実験結果}

\section{1 柱脚部における入力地震動}

本試験体は, 震動台の大きさ $(20 \mathrm{~m} \times 15 \mathrm{~m})$ を超える大きさであり， 基礎梁が震動台から大きく張り出した構造をしている。そのため, 震動台上の入力地震動は基礎梁により伝達されることになる。ここ で片持ち梁となっている基礎梁の振動を確認する。

図 7 に K-NET 仙台波 100\%加振時に計測した柱脚部の応答加速 度から求めた加速度応答スペクトルを示す。これによると，水平 2 方向については, 目標とする加速度応答スペクトルに近く, 十分な 再現性がある。一方，鉛直方向については，周期約 0.3 秒よりも長 い成分については概㸚目標に近い值であるが, 周期約 0.1 秒で大き な応答増幅がある。この傾向は特に角部(X1Y1)で著しく大きくな っている。周期の短い高次モードの分析では, 現実の体育館に入力 される地震動とは大きく異なっている点を念頭に置いて事実を分 析する必要があるものの，応答に特に重要である 1 次モードの振
動は十分再現できている。

\section{2 固有周期と減衰定数の推定}

地震波による加振実験を実施する前に $0.1 〜 35 \mathrm{~Hz}$ の範囲の成分 が含まれたホワイトノイズ加振を行っている。この加振の結果を用 いて、震動台上に取り付けられた加速度計で計測された加速度に対 する，各部材に取り付けられた加速度計により計測された応答加速 度の周波数分析を行い伝達関数を求め, この結果を用いてカーブフ イット法を適用し，固有周期と減衰定数の同定した。

図 8 は梁間方向 1 方向入力のホワイトノイズ加振により同定した 1 次固有モードである。中央構面 $(\mathrm{X} 4)$ には水平方向入力により鉛直 振動が励起しており, 柱頭の水平振動の振幅 $\mathrm{H}_{\text {col }}$ に対する、屋根各 測定点の鉛直振動 $V_{\text {roof }}$ の比 $V_{\text {roof }} / H_{\text {col }}$ を求めると最大 $32 \%$ となった。 一方, 妻面(X1)については, ターンバックルブレースにより固めら れていることも有り， $\mathrm{V}_{\text {roof }} / \mathrm{H}_{\text {col }}$ はほぼ 0 となり鉛直振動はほとんど 励起していない。これに対し、屋根各測定点の水平振動 $\mathrm{H}_{\text {roof }}$ との比 $\mathrm{H}_{\text {roof }} / \mathrm{H}_{\text {col }}$ を求めると, 中央構面 $(\mathrm{X} 4)$, 妻面(X1) ともほぼ 1 となり、 柱頭と屋根面はほぼ同一の水平振動をしている。

これに対し，2．２節で求めた応答増幅率は水平方向 1.28 , 鉛直 方向 1.08 であり，屋根面の応答加速度の鉛直方向の振幅は，水平方 向の $84 \%$ に相当し，大きな鉛直振動が生じると評価されている。し かし，実験では，水平方向の振幅の $32 \%$ 程度と，水平方向と鉛直方 向の連成はあるものの, 大きな振幅ではなく, 2 . 2 節で求めた応 答増幅率は過大に評価されている。個々の加速度計の応答を分析す るなど,さらなる検討を進めたい。

表 5 は各地震波の加振実験前に実施した 3 方向同時入力のホワイ トノイズ加振に基づいて求めた固有周期と減衰定数の推定值である。

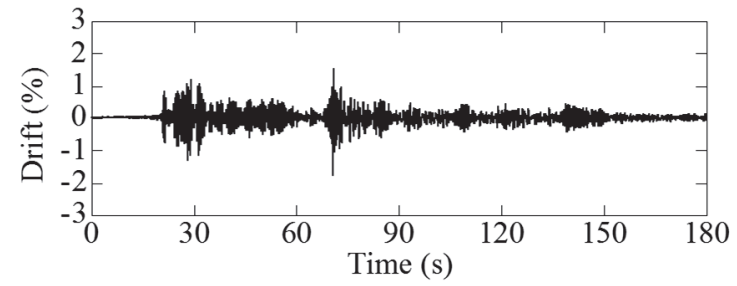

(a) 梁間方向

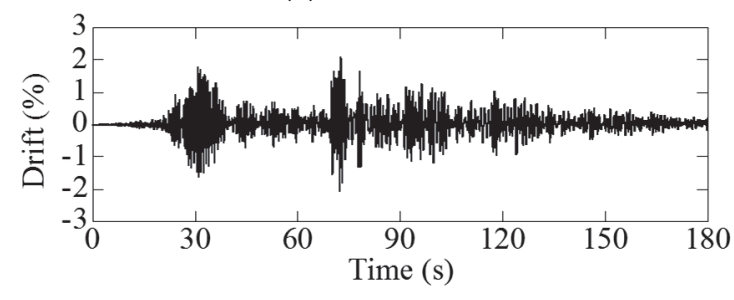

(b) 桁行方向

図 9 全体変形角の時刻歴応答 (耐震天井試験体 K-NET 仙台波 $100 \%$ 加振) 
表 6 全体変形角(\%)の最大値

\begin{tabular}{|c|c|c|c|}
\hline \multirow{2}{*}{ 種別 } & \multirow{2}{*}{$\begin{array}{l}\text { 入力地震動 } \\
\text { 加振レベル }\end{array}$} & \multicolumn{2}{|c|}{ 全体変形角 } \\
\hline & & 梁間方向 & 桁行方向 \\
\hline \multirow{3}{*}{$\begin{array}{l}\text { 未対策 } \\
\text { 天井 }\end{array}$} & K-NET 仙台波 $25 \%$ & $0.27 \%$ & $0.17 \%$ \\
\hline & K-NET 仙台波 50\%(1) & $0.68 \%$ & $0.42 \%$ \\
\hline & K-NET 仙台波 50\%(2) & $0.65 \%(\%)$ & $0.52 \%{ }^{(\%)}$ \\
\hline \multirow{6}{*}{$\begin{array}{l}\text { 耐震 } \\
\text { 天井 }\end{array}$} & K-NET 仙台波 25\% & $0.28 \%$ & $0.18 \%$ \\
\hline & K-NET 仙台波 50\% & $0.65 \%$ & $0.41 \%$ \\
\hline & K-NET 仙台波 80\% & $1.14 \%$ & $1.03 \%$ \\
\hline & K-NET 仙台波 100\% & $1.81 \%$ & $2.09 \%$ \\
\hline & JMA 神戸波 100\% & $1.45 \%$ & $3.20 \%$ \\
\hline & JMA 神戸波 $150 \%$ & $2.05 \%(※)$ & $4.47 \%(※)$ \\
\hline
\end{tabular}

$(※)$ 加速度データを 2 回直接積分して算出された值

未対策天井から耐震天井に天井を入れ替えた実験を行ったが，未対 策天井の場合でも, 耐震天井の場合でも固有周期, 減衰定数とも大 きな変化はない。また，これらの值は 2.4 節での検討に用いた 3 次 元フレーム解析モデルとほぼ同じかやや長い程度であった。なお, 前述した 1 方向加振と比較すると, 固有周期は同じであったが, 減 衰定数が約半分となった。減衰定数の振幅依存性などに起因してい るものと考えられる。

\section{3 全体変形角と層せん断力}

図 9 は K-NET 仙台波 $100 \%$ 加振時の屋根中央における応答変位 を高さで除した全体変形角である。また, 表 6 は全体変形角の最大 值を各加振毎にまとめたものである。なお，屋根中央の変位は測定 点に取り付けた複数のワイヤー式変位計の測定結果から各方向の成 分に変換して求めたものであるが，一部の加振実験では脱落した天

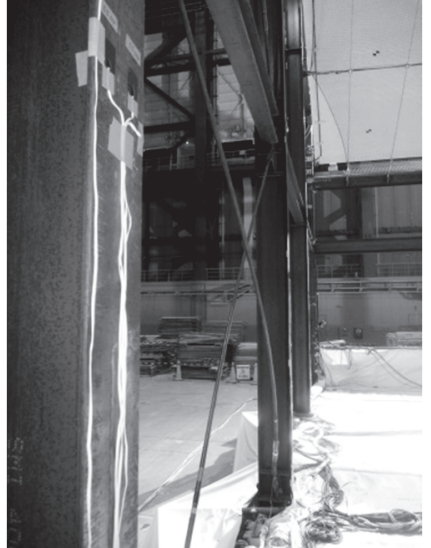

写真 2 K-NET 仙台波 $80 \%$ 加振後の壁ブレースの座屈変形

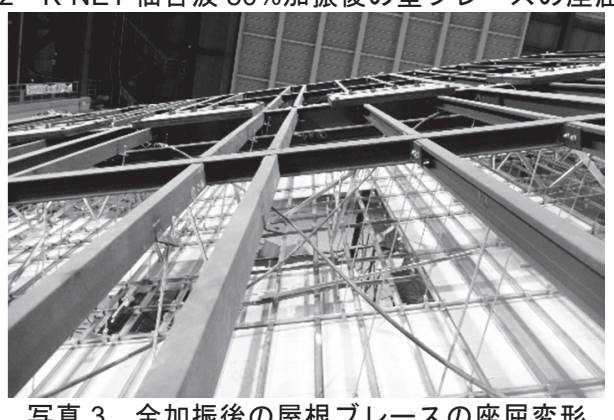

写真 3 全加振後の屋根ブレースの座屈変形

井材がワイヤーに接触したことによりうまく測定できなかった。そ のため，表 6 中の一部の加振実験の結果は加速度計の測定結果を 2

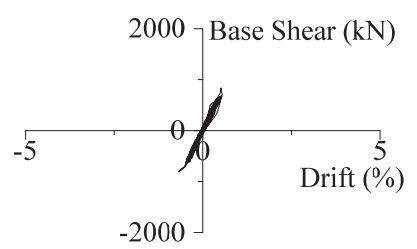

(i) 梁間方向

$2000\urcorner$ Base Shear $(\mathrm{kN})$

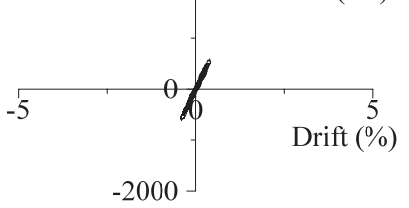

(ii) 桁行方向

(a) K-NET 仙台波 50\%

(未対策天井)

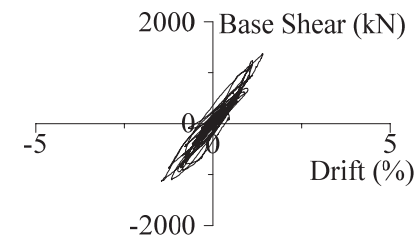

(i) 梁間方向

$2000 \_$Base Shear $(\mathrm{kN})$

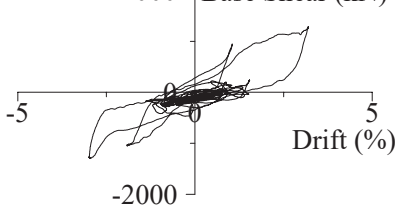

(ii) 桁行方向

(d) JMA 神戸波 100\%

(耐震天井)

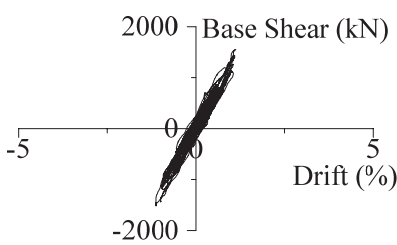

(i) 梁間方向

$2000\urcorner$ Base Shear $(\mathrm{kN})$

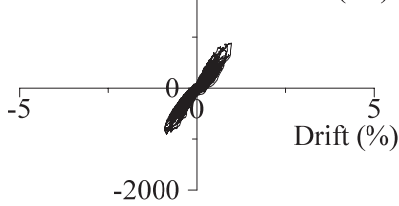

(ii) 桁行方向

(b) K-NET 仙台波 $80 \%$

(耐震天井)

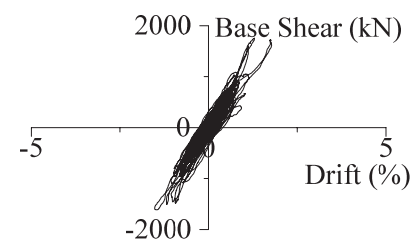

(i) 梁間方向

2000 Base Shear $(\mathrm{kN})$

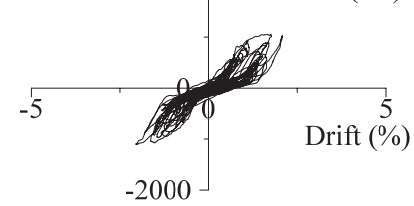

(ii) 桁行方向

(c) K-NET 仙台波 100\%

(耐震天井)

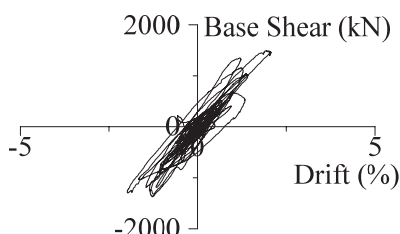

(i) 梁間方向

$2000\urcorner$ Base Shear $(\mathrm{kN})$

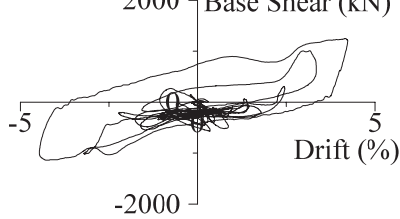

(ii) 桁行方向

(e) JMA 神戸波 150\%

(耐震天井) 
表 7 各加振での屋根面最大加速度応答の平均值 $\left(\mathrm{m} / \mathrm{s}^{2}\right)$

\begin{tabular}{|c|c|r|r|r|}
\hline $\begin{array}{c}\text { 天井 } \\
\text { 試験体 }\end{array}$ & 加振レベル & 梁間 & 桁行 & 上下 \\
\hline \multirow{3}{*}{$\begin{array}{c}\text { 未対策 } \\
\text { 天井 }\end{array}$} & K-NET 仙台波 $25 \%$ & 13.7 & 19.6 & 13.7 \\
\cline { 2 - 5 } & K-NET 仙台波 $50 \%(1)$ & 26.5 & 32.4 & 24.5 \\
\cline { 2 - 5 } & K-NET 仙台波 50\%(2) & 27.5 & 34.3 & 26.5 \\
\hline \multirow{4}{*}{ 耐震 } \\
天井 & K-NET 仙台波 $25 \%$ & 11.8 & 13.7 & 9.8 \\
\cline { 2 - 5 } & K-NET 仙台波 50\% & 23.5 & 29.4 & 22.6 \\
\cline { 2 - 5 } & K-NET 仙台波 $80 \%$ & 39.2 & 41.2 & 33.3 \\
\cline { 2 - 5 } & K-NET 仙台波 100\% & 41.2 & 41.2 & 31.4 \\
\cline { 2 - 5 } & $\mathrm{JMA}$ 神戸波 $100 \%$ & 36.3 & 41.2 & 29.4 \\
\cline { 2 - 5 } & $\mathrm{JMA}$ 神戸波 $150 \%$ & 39.2 & 43.1 & 31.4 \\
\hline
\end{tabular}

回積分して求めた。なお, 加速度の積分にあたり, カットオフ周波 数 $1 \mathrm{~Hz}$ もしくは $1.5 \mathrm{~Hz}$ のローパスフィルターを用いて長周期成分 の影響を除去している。これらのカットオフ周波数は, 変位が正し く測定されていた K-NET仙台波 50\%加振およびJMA 神戸波 100\% 加振において, 変位計の計測結果と加速度計の積分結果が整合する 結果となる值を求めたものである。適切な積分方法については今後 さらに検討したい。

入力レベルが小さいうちは梁間方向の応答が，桁行方向に比較し て大きいが，K-NET 仙台波 $80 \%$ 加振よりも大きくなると桁行方向 の応答の方が大きくなる。桁行方向の応答は壁ブレースが支配的で 有り, ブレースに貼り付けたひずみゲージの測定結果によれば, 壁 ブレースが塑性化を始める加振は K-NET 仙台波 80\%加振以降であ る事実に矛盾しない結果となっている。

壁ブレースのひずみから求めたブレースの軸力と, 柱に取り付けた ひずみから求めたせん断力の合算から作用層せん断力を求めると図 10 のようになる。なお, 鋼材の応力ーひずみ関係は完全弾塑性でモ デル化した。

柱に作用したモーメントによると柱基部の作用モーメントが降伏 モーメントに達するのは K-NET 仙台波 80\%加振以降であり, 図 10 に示した梁間方向の全体変形角〜層せん断力関係は K-NET 仙台波 50\%加振までは弾性範囲にある。また, 降伏モーメントに達した後 も耐力の上昇があるため, 履歴ループの形状も大きく膨らまない。

これに対し, 桁行方向では K-NET 仙台波 80\%加振により壁ブレ 一スが塑性化するため, 全体変形角一層せん断力関係も塑性化の影 響が現れ，スリップ性状が出てくる。桁行方向はブレースが支配的 となるよう設計されているため,ブレースの塑性化の影響が大きい。

写真 2 は K-NET 仙台波 $80 \%$ 加振後の壁ブレースの変形である。 座屈により面外方向に大きくはらみだしていることがわかる。

写真 3 は全加振実験終了後の屋根ブレースの変形である。繰り返 して加振実験を行うことで,かなり大きな塑性変形を繰り返し与え, 屋根ブレースは大きくたわんだが， 1 本も破断することなく実験を 終了した。

\section{4 屋根面応答加速度}

図 11 に未対策天井の K-NET 仙台波 50\%加振 1 回目の屋根面の 応答加速度を示す。また, 屋根面に取り付けた 35 の加速度計の計 測結果の最大值を求め, その 35 の最大值の最大, 平均, 最小を求め て図 12 に, そのうち平均を表 7 に示す。

屋根面の応答加速度には, 高振動数の成分が多く含まれており,

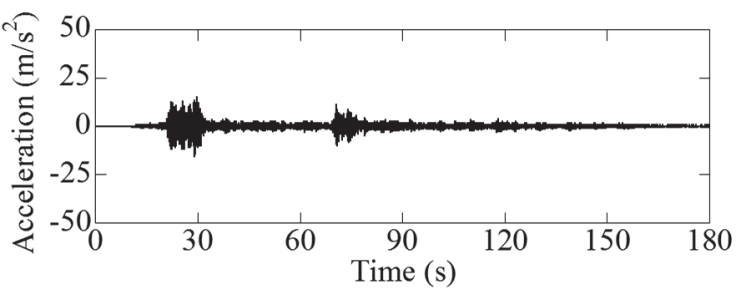

(a) 梁間方向

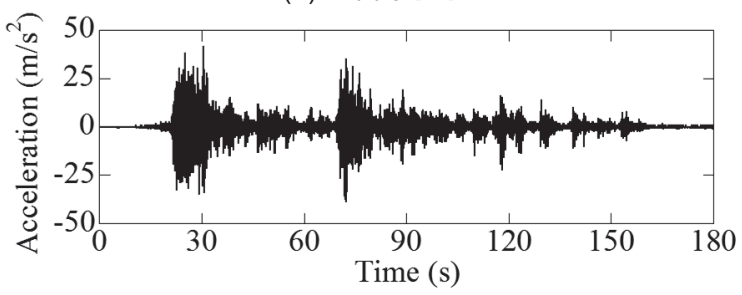

(b) 桁行方向

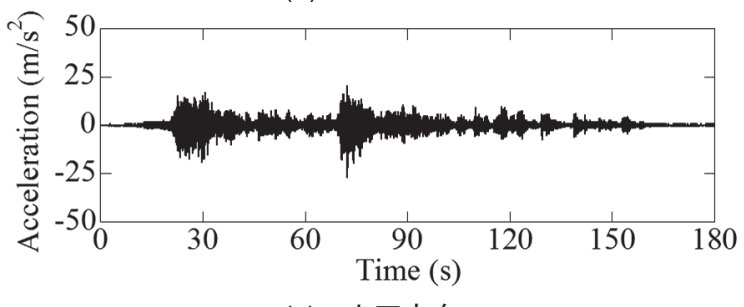

(c) 上下方向

図 11 屋根面加速度応答(X4Y5 通り)

（未対策天井，K-NET 仙台波 50\%加振 1 回目）

加速度の最大值も表 4 に示した目標とする屋根面加速度よりも大き な応答であった。これは, 前述した基礎梁の 0.1 秒付近の鉛直振動 増幅の影響の他, 図 1 に示寸とおり, 屋根錘が大梁に取り付けられ た母屋材に接触しやすい構造であったことにより, 接触による加速 度含まれているためと考えられる。

図 12 のうち, 平均值に着目すると柱やブレースが塑性化する KNET 仙台波 80\%程度までは入力レベルの増加に伴い大きくなって いるが，これ以上の加振では概ね一定の加速度を示しており，塑性 化の事実と矛盾しない結果となっている。最大值や最小值を見ると 屋根面の応答は測定点によって值が異なりばらつきがあることがう かがえる ${ }^{11)}$ 。個々の加速度応答については, 続報以降でさらなる分 析を進めたい。

\section{5 作用モーメント分布の推定}

柱と屋根大梁の断面でのひずみ計測值により山形ラーメン架構の 曲げモーメント分布を推測する。耐震天井試験体の K-NET 仙台波 $50 \%, 80 \%, 100 \%$ 加振時において,ひずみゲージ貼り付け位置では, 部材が弹性状態を保っていると仮定して算出した柱脚部曲げモーメ ント $M_{b}$ が最大となる時点の $\mathrm{X} 4$ 通りの山形ラーメン架構の曲げモ 一メント分布を図 13 に示寸。同図中に $M_{b}$ の值を括弧内に示してい る. 山形ラーメン架構の柱材, 大梁の断面は $\mathrm{H} 400 \times 200 \times 8 \times 13$ であ り, その降伏曲げモーメント M y $350 \mathrm{kNm}$, 全塑性曲げ而力 $M_{p}$ は $392 \mathrm{kNm}$ である。K-NET 仙台波 50\%加振では弹性状態に留まっ ているが，K-NET 仙台波 $80 \%$ 加振で $M_{p}$ 近傍まで増加し，さらに K-NET 仙台波 $100 \%$ 加振では柱脚部モーメントは数回 M p に達する。 JMA 神戸波 $100 \% ， 150 \%$ 加振についても柱脚部は数回 M p に達し ている。加振終了後に, 目視により柱脚部の損傷状態を確認したが, 柱脚部に目立った損傷は見られなかった。

3. 6 ブレースの塑性化状況 


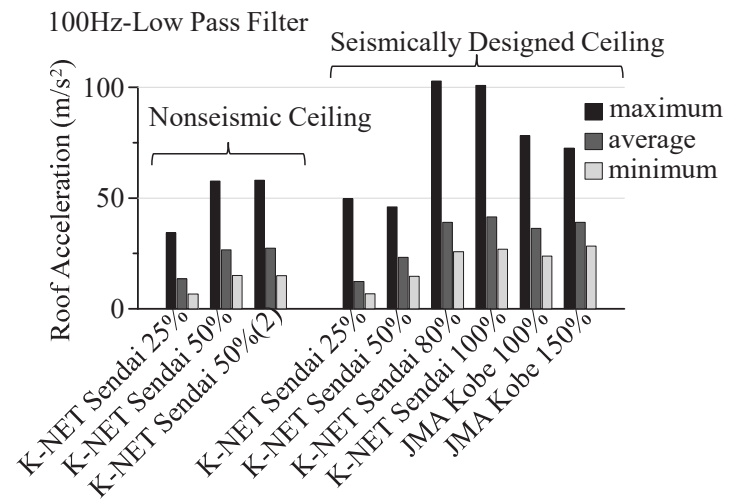

(a) 梁間方向

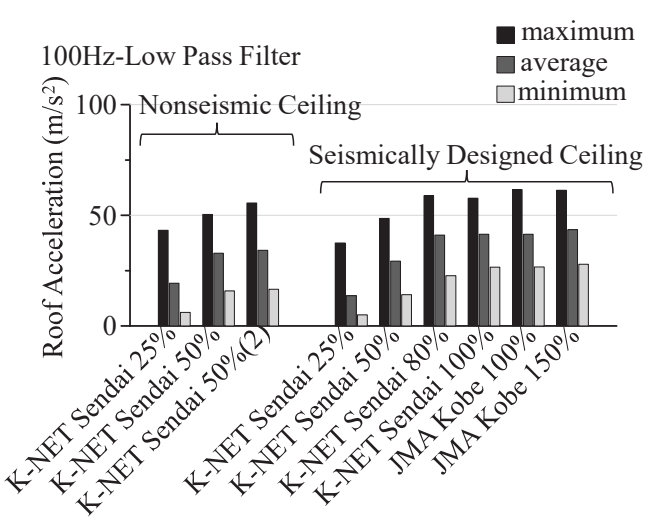

(b) 桁行方向

maximum

$\square$ average

$\square$ minimum

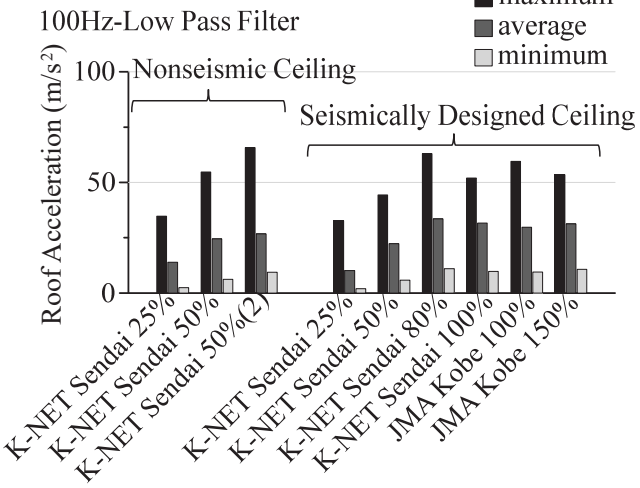

(c)上下方向

図 12 各加振での屋根面最大加速度応答の最大值, 平均値, 最小値
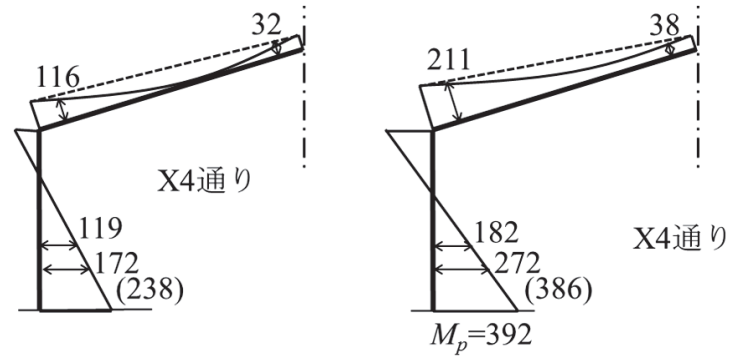

(a) K-NET 仙台波 50\%加振

(b) K-NET 仙台波 $80 \%$ 加振

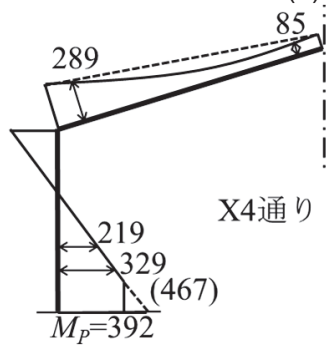

(c) K-NET 仙台波 $100 \%$ 加振

図 13 山形ラーメン架構の曲げモーメント分布(X4 通り)

各加振における, ひずみを計測した梁間方向, 桁行方向の壁ブレ ース各 10 個のひずみ計測結果を用いて評価した壁ブレースの作用 軸力 $\sum P$ の降伏軸力 $\sum P_{y}$ に対する割合(以下、作用軸力比とする)を 図 14 に示す。ここで作用軸力 $\sum P$, 降伏軸力 $\sum P_{y}$ は以下の式で算 出した。

$$
\begin{aligned}
& \sum \mathrm{P}=\sum_{\mathrm{i}=1}^{\mathrm{n}} \mathrm{P}_{\mathrm{i}}=\sum_{\mathrm{i}=1}^{\mathrm{n}}\left(\mathrm{A} \times \sigma_{\mathrm{i}}\right) \\
& \sum \mathrm{P}_{\mathrm{y}}=\mathrm{n} \times \mathrm{A} \times \sigma_{\mathrm{y}}
\end{aligned}
$$

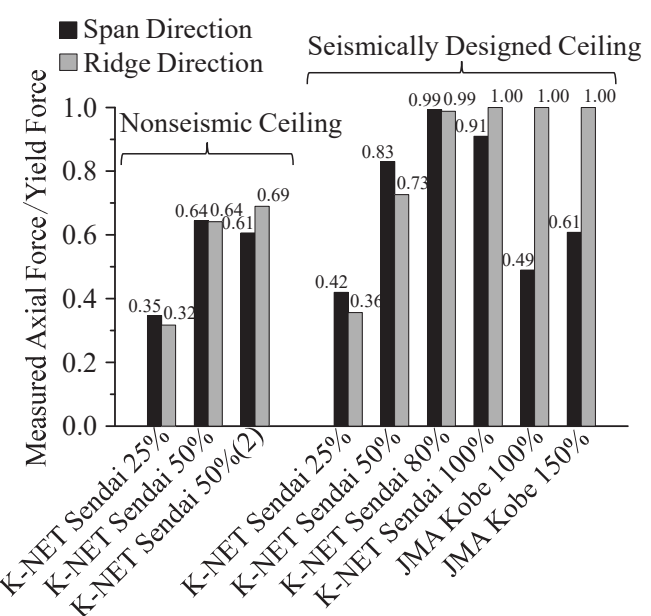

図 14 壁ブレースの作用軸力比の推移

ここで，nはひずみを計測した壁ブレースの個数であり，梁間，桁 行方向ともに 10 である。A は壁ブレースの断面積, $\sigma_{\mathrm{y}}$ は降伏応力, $\sigma_{\mathrm{i}}$ は完全弾塑性を仮定して得られた $\mathrm{i}$ 番目のブレースの作用応力 である。

K-NET 仙台波 $25 \%$ 加振， $50 \%$ 加振では全ての壁ブレースが弾性 域にあり，K-NET 仙台波 $25 \%$ 加振では梁間，桁行方向ともに降伏 軸力の 0.3 倍程度, K-NET 仙台波 50\%加振では $0.6 \sim 0.8$ 倍程度の 軸力が作用した。 K-NET 仙台波 80\%加振では, 梁間方向で $80 \%$, 桁行方向で $50 \%$ の壁ブレースが降伏した。これ以降の K-NET 仙台 波 100\%加振、JMA 神戸波 100\%加振、JMA 神戸波 150\%加振では、 作用軸力比が小さくなっている。これは、ブレースの塑性化による 塑性変形によってブレース全長が伸びてしまい、ブレースが抵抗し 


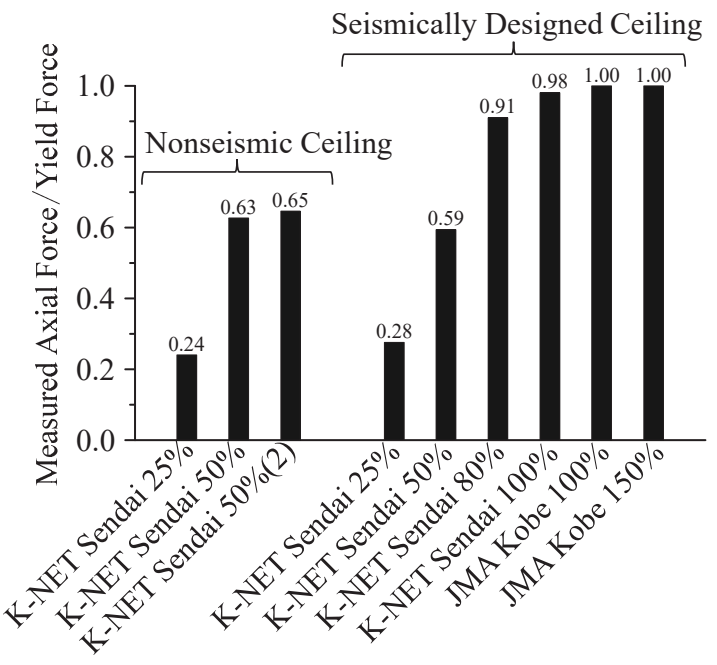

図 15 屋根ブレースの作用軸力比の推移

なくなっているためである。

ひずみゲージを貼り付けた屋根面屋根ブレース 36 個の作用軸力 比を図 15 に示す。未対策天井試験体について, K-NET 仙台波 $25 \%$ 加振時では全ての屋根面屋根ブレースが弾性域に留まり, 降伏軸力 の 0.25 倍程度の軸力が作用した. K-NET 仙台波 $50 \%$ 加振 1 回目で 屋根面屋根ブレース 36 個のうち $11 \%$ が降伏し, K-NET 仙台波 $25 \%$ 加振 2 回目では 17\%が降伏した。一方, 耐震天井試験体では, KNET 仙台波 $50 \%$ 加振時までは全ての屋根面屋根ブレースが弾性域 に留まり, K-NET 仙台波 50\%加振で降伏軸力の 0.6 倍程度の軸力 が屋根面屋根ブレースに作用した。K-NET 仙台波 $80 \%$ 加振では、 外周四辺一列の屋根ブレースは全て降伏しており、その内側の屋根 ブレースは多くが弾性にとどまっている。その後の加振により塑性 化はさらに進行し、JMA 神戸波 100\%加振および JMA 神戸波 150\% 加振では、全ての屋根ブレースが降伏した。

\section{4. まとめ}

大規模空間に設置された吊り天井の脱落被害メカニズム解明のた め, 吊り天井を有する実大体育館の加振実験実施した。本論文では, 実験計画として, 試験体の概要, 主要な構造体の計測計画および加 振計画について述べるとともに, 構造体の振動特性と試験体の挙動, 塑性化の状況について検証した。まとめると以下のようになる。

（1）直接基礎上に建設された体育館の挙動を再現できるよう柱脚 部，基礎梁の応答に配慮して試験体を設計した。Ai 分布を用 いたプッシュオーバー解析の結果, 試験体がプロトタイプの 挙動が再現できることを確認した。

（2）柱脚部で計測された加速度を確認した結果，水平 2 成分およ び鉛直成分の 1 次固有振動数付近の振動成分は十分な再現性 を有しており、現実の体育館の挙動を概数再現できている。 ただし，基礎梁が震動台から大きく張り出しているために $10 \mathrm{~Hz}$ 程度の鉛直振動が励起されているため, 高次モードの 振動などの高振動成分を用いた分析では十分な検討が必要で ある。

（3）試験体の固有周期と固有モードおよび減衰定数の推定を行っ
た。その結果, 屋根面において水平入力に対して鉛直振動が 励起していることが確認され, その振幅は水平振動の振幅に 対して, 最大 $32 \%$ となった。また，減衰定数は $1.8 \sim 2.4 \%$ と 一般的に用いられる減衰の值を示している。

（4）実験により最大の層間変形角として, 梁間方向で $2.05 \%(=1 / 49)$, 桁行方向に $4.47 \%(=1 / 22)$ の変形が生じたが, 柱がわずかに降伏したのみであり，柱および梁には損傷は生 じなかった。これに対して, 壁ブレースや屋根ブレースは多 数回繰り返して大きく塑性化するとともに座屈し，面外方向 に大きくはらみだした。ただし, 破断にまでは至っていない。

\section{謝辞}

防災科学技術研究所の運営費交付金 PJによる学校施設における 大空間建築物の実験研究分科会（委員長壁谷澤寿海教授）の下部組 織である実験検討ワーキングでは，(株)桐井製作所荒井智一氏，（国 研)建築研究所石原直氏, 東京大学伊山潤准教授, 八潮建材工業株式 会社岩下裕樹氏, 横浜国立大学江口亨准教授, 堀江建築工学研究所 太田勤氏，三洋工業株式会社金井貴浩氏，(株)オクジュー高岡昌史 氏，(株)竹中工務店吉澤睦博氏(50 音順)より，実験計画策定と試験 体設計に関し，多数のご助言をいただいた。また，文部科学省大臣 官房文教施設企画部施設企画課防災推進室に文教施設に関する情報 を多数提供いただいた。ここに記して厚くお礼を申し上げる。

\section{参考文献}

1）山田哲, 伊山潤, 島田侑子, 松本由香, 長谷川隆, 清家剛, 中野達也, 吉 敷祥一: 東北地方太平洋沖地震および余震による学校体育館の構造被害, 日本建築学会技術報告集, Vol. 20, No. 44, pp. 133-138, 2014. 2 .

2）清家剛，江口亨，熊谷亮平，佐藤考一，名取発，脇山善夫，井上朝雄，山 田哲, 島田侑子 : 東北地方太平洋沖地震および余震による学校施設の校舎 と体育館の非構造部材の震動被害, 日本建築学会技術報告集, Vol. 20, No. 44, pp. 405-410, 2014.2.

3）山田哲, 江口亨, 松本由香, 清家剛, 伊山潤, 熊谷亮平, 島田侑子: 東北 地方太平洋沖地震および余震による学校体育館の構造特性と非構造部材の 震動被害, 日本建築学会技術報告集, Vol. 20, No. 46, pp. 981-986, 2014. 10.

4）江口亨, 清家剛, 熊谷亮平, 松本由香, 伊山潤, 山田哲, 椛山健二, 楠浩 一: 東北地方太平洋沖地震および余震による学校施設の校舎における天井 の震動被害, 日本建築学会技術報告集, Vol. 21, No. 47, pp. 55-59, 2015. 2.

5）建築基隻法施行令の一部を改正する政令，平成 25 年政令第 217 号.

6) 平成 25 年国土交通省告示第 771 号, 特定天井および特定天井の耐力上安 全な構造方法を定める件。

7）一般社団法人 建築性能基準推進協会: 建築物における天井脱落対策に倸 る技術基淮の解説， 2013 .

8）竹内徹, 小河利行, 山形智香, 熊谷知彦: 支持架構付き屋根型円筒ラチ スシェルの地震応答評価, 日本建築学会構造系論文集, №. 596, pp. 57-64, 2005. 10 .

9）竹内徹, 熊谷知彦, 調浩朗, 小河利行 : 多層架構で支持されたラチスシ エル構造の地震応答評価, 日本建築学会構造系論文集, №. 619, pp. 97-104, 2007. 9.

10）文部科学省: 学校施設における非構造部材の耐震対策の推進に関する調 査研究報告書一校舎等におうる非構造部材の耐震対策の推進について一, 学校施設における非構造部材の耐震対策の推進に関寸る調查研究協力者会 議, 2014.

11）鈴木理恵, 佐藤大樹, 佐々木智大, 青井淳, 梶原浩一, 田川浩之： $\mathrm{E}-$ ディフェンス震動台実験による実大鉄骨造体育館の屋根面の応答性状，日 本地震工学会大会 2015 梗概集, pp. 3-13，2015. 


\title{
DESIGN AND STRUCTURAL RESPONSE OF FULL-SCALE STEEL GYMNASIUM SPECIMEN
}

E-Defense shake table experiment on collapse mechanism of wide-area suspended ceiling in gymnasium part 1

\author{
Tomohiro SASAKI*1 , Atsushi AOI*2, Hiroyuki TAGAWA*3, \\ Koichi KAJIWARA *4, Daiki SATO ${ }^{* 5}$, Toshimi KABEYASAWA*6, \\ Tsuyoshi SEIKE ${ }^{* 7}$, Satoshi YAMADA ${ }^{* 8}$ and Hiroshi FUKUYAMA ${ }^{* 9}$
}

\footnotetext{
${ }^{*}$ Senior Researcher, Earthquake Disaster Mitigation Division, Natl. Res. Inst. for Earth Science and Disaster Resilience, Dr. Eng. ${ }^{* 2}$ Researcher, R\&D Inst., Takenaka Corp, M. Eng. (Former Natl. Res. Inst. for Earth Science and Disaster Resilience)

*3 Assoc. Prof., Dept. Arch., Mukogawa Women's Univ, Ph. D. (Former Natl. Res. Inst. for Earth Science and Disaster Resilience)

${ }^{*} 4$ Manager, Earthquake Disaster Mitigation Division, Natl. Res. Inst. for Earth Science and Disaster Resilience, Dr. Eng.

${ }^{*}$ Assoc. Prof., FIRST, IIR, Tokyo Tech, Dr. Eng. (Former Natl. Res. Inst. for Earth Science and Disaster Resilience)

${ }^{6}$ Prof., Earthquake Res. Inst., The Univ. of Tokyo, Dr. Eng.

${ }^{* 7}$ Assoc. Prof., Dept. Socio-Cultural Env. Studies, The Univ. of Tokyo, Dr. Eng.

${ }^{*} 8$ Prof., FIRST, IIR,, Tokyo Tech., Dr. Eng.

${ }^{* 9}$ Director, Housing Dept., Natl. Inst. for Land and Infrastructure Mgt., Dr. Eng.
}

In the 2011 off the Pacific coast of Tohoku Earthquake, many suspended ceilings and other suspended equipment fell down due to the lack of their resistance to earthquakes. To mitigate severe damage to ceiling system caused by earthquakes, new seismic design code for suspended ceiling system was issued by the Ministry of Land, Infrastructure, Transport and Tourism. However, the mechanism why and how suspended ceiling system falls down during earthquakes has not yet been clarified well. In order to clarify the collapse mechanism of wide-area ceiling system and development of its countermeasure, new research project was launched and the first series of full-scale shake table experiments of wide-area ceiling system in school gymnasium was conducted. This paper presents outline of the full-scale shake table experiment and global response of structural members.

The specimen was designed as the full-scale specimen which can represents real steel school gymnasium on spread foundations built in elementary and junior high schools based on the allowable stress design with base shear coefficient $\mathrm{C}_{0}$ of 0.2 . It had a floor plan dimension of $30 \mathrm{~m}$ by $18.6 \mathrm{~m}$ and a height of $9.09 \mathrm{~m}$. Because its size was larger than the shake table size of $20 \mathrm{~m}$ by $15 \mathrm{~m}$, it was supported by cantilevered large stiff girders with the overhang of $5 \mathrm{~m}$ at the maximum. Based on pushover analysis using $A_{i}$ distributions, it was confirmed that the base-shear versus displacement relation in the specimen was close to that in the prototype of the specimen. In the specimen, two different types of suspended ceiling were installed; 1) non-seismic ceiling and 2) seismically designed ceilings with seismic coefficient of $1.1 \mathrm{G}$ and $2.2 \mathrm{G}$. Fail-safe system consisting of wires and nets to prevent damage caused by suspended equipment to people inside the gymnasium was also installed to evaluate its effectiveness.

Two ground acceleration records were used as imposed motions; 1) K-NET Sendai record observed at K-NET Sendai station during the 2011 off the Pacific coast of Tohoku Earthquake and 2) JMA Kobe record observed at JMA Kobe observatory during 1995 Hyogo-ken Nanbu earthquake. Intensity of imposed motions were 5\%, 25\% and 50\% (twice) of K-NET Sendai record for the specimen with non-seismic ceiling and 5\%, 25\%, 50\%, 80\% and 100\% of K-NET Sendai record and $100 \%$ and $150 \%$ of JMA Kobe record for the specimen with seismically designed ceilings.

Based on the shake table experiment, it was found that response accelerations measured at the base of corner columns (the edge of cantilevered stiff girders) were close to the original record in horizontal directions while vertical response accelerations were amplified in the frequency of $10 \mathrm{~Hz}$. It showed the response acceleration should be carefully checked in high frequency components.

Based on the whitenoise excitations, natural periods and mode shapes were estimated. It was clarified that the vertical response was coupled with horizontal response and the intensity of vertical response was the maximum value of $32 \%$ of the intensity of horizontal response.

Based on the excitations using K-NET Sendai and JMA Kobe records, the maximum response displacement at the roof top was $2.05 \%(=1 / 49)$ and $4.47 \%(=1 / 22)$ of the height of specimen in span and ridge directions, respectively. Only the base of columns yielded, however, no damage was observed in columns, girders and beams. All vertical and horizontal braces yielded and buckled repeatedly, and the deformation in the out-of-plane direction was observed. However, no brace ruptured. 